J. Linguistics 57 (2021), 871-905. C The Author(s), 2021.

Published by Cambridge University Press. This is an Open Access article, distributed under the terms of the Creative Commons Attribution licence (http://creativecommons.org/licenses/by/4.0/), which permits unrestricted re-use, distribution, and reproduction in any medium, provided the original work is properly cited.

doi: $10.1017 /$ S0022226720000481

\title{
Catalan focus markers as discourse particles ${ }^{1}$
}

\author{
ANDREAS TROTZKE(D) \\ Universität Konstanz \\ LAIA MAYOL (10) \\ Universitat Pompeu Fabra
}

(Received 02 April 2019; revised 30 September 2020)

In this paper, we investigate focus markers in Catalan that can take on discourse-particle readings. We focus on two Catalan elements that have not been studied from a formal linguistics perspective so far: the focus adverb precisament 'precisely' and the focus particle també 'also'. We demonstrate that these elements feature interpretations that we identify as a type of meaning familiar from discourse particles in languages other than Catalan. After having outlined the basic distribution and interpretative effects of these particles, we analyze the semantics and pragmatics of precisament and també within a probabilistic argumentative framework, and we then conclude the paper by comparing the observations and analyses we have pointed out for Catalan to other languages that feature a discourse-particle reading of similar focus markers.

KEYWORDs: Catalan, discourse particles, focus adverbs, focus particles, pragmatics, semantics

\section{INTRODUCTION}

Discourse particles have been attested in a wide range of languages (see e.g. Zimmermann 2011, Grosz to appear for overviews), and they display several properties that distinguish them from other word classes. The most important properties in the context of our paper are that (i) most of them have counterparts in other word classes that are identical in form, and (ii) they do not influence the

[1] We are very grateful to the three anonymous Journal of Linguistics referees, who gave extremely detailed and helpful comments, which greatly improved the paper. We also thank Anastasia Giannakidou and Joan Mascaró for feedback and discussion. Andreas Trotzke gratefully acknowledges financial support from the Beatriu de Pinós program (Generalitat de Catalunya/Secretariat for Universities and Research of the Ministry of Economy and Knowledge; grant no. 2017BP00031). Laia Mayol has been supported by the project QUDLE (PGC2018-094029-A-I00) funded by the Ministry of Science and Innovation (MCI)/Spanish Research Agency (AEI) and the European Regional Development Fund (FEDER, EU).

The following abbreviations are used in the glosses: $\mathrm{ACC}=$ accusative, $\mathrm{ADD}=$ additive marker, $\mathrm{CL}=$ clitic pronoun, $\mathrm{COP}=$ copula, $\mathrm{PART}=$ particle, $\mathrm{PRS}=$ present tense marker, $\mathrm{PST}=$ past tense marker, $\mathrm{PVE}=$ partitive pronoun, $\mathrm{SG}=$ singular. 
truth-conditional meaning of the host sentence. There is a debate in the literature whether these non-truth-conditional meanings are really conventionally implicated (Kratzer 1999, Potts 2005, McCready 2010, Gutzmann 2015) or truth-conditionally vacuous presupposition triggers (Egg \& Zimmermann 2012, Grosz 2014a). In this paper, we will contribute to this debate with the analysis of two discourse particles in Catalan where the counterparts are focus markers in the form of both focus particles and focus adverbs. $^{2}$

Catalan syntax-discourse phenomena as well as related lexical items have already been investigated in great detail in the existing literature from a formal linguistics perspective (e.g. Castroviejo 2006, Villalba 2008, Mayol \& Castroviejo 2009, Mayol \& Clark 2010). However, to the best of our knowledge, there are very few studies that investigated Catalan discourse particles from a formal perspective so far, let alone their relationship with their focus-marker counterparts. Although it has already been pointed out that Catalan is a language with a rich inventory of discourse particles (e.g. Espinal 2011, Torrent 2011), the only detailed formal study on Catalan discourse particles is Rigau's (2012) syntactic work on the particle pla (roughly meaning 'it's sure'), which is restricted to certain north-eastern varieties of Catalan. We will show below that, interestingly, some Catalan focus markers can take on a meaning which qualifies as a kind of meaning that we observe for discourse particles in other languages.

Specifically, we first introduce and demonstrate in Section 2 below that the Catalan focus particle també 'also' and the focus adverb precisament 'precisely' both feature a discourse-particle interpretation, in addition to their focus-marker reading. In particular, the focus particle també can take on an expressive reading such that the speaker conveys a negative attitude towards the proposition by using també. The focus adverb precisament, on the other hand, can emphatically assert an (unexpected) identity of two values or arguments in two different propositions. In Section 3, we will account for our observations within a probabilistic argumentative framework and provide a detailed analysis of the semantics and discourse properties of both també and precisament. Given this analysis, we will then turn to crosslinguistic comparisons of similar particles in other languages, and we will also address the more general question of how clear the categorial distinction between focus markers and discourse particles can be drawn at all, given their close semantic relationship we are observing in this paper. ${ }^{3}$

[2] The advantage of using the label 'focus markers' is that it covers both adverbs and particles, and, in contrast to other terms such as 'focus-sensitive elements' or 'focusing modifiers' (e.g. De Cesare 2015), the term 'focus marker' is meant to exclude discourse particles. Note that the main function of discourse particles is certainly not to 'mark' focus, although they are also both focus-sensitive and modifiers (even if at an illocutionary level). To our mind, the term focus marker is thus the best solution for our purposes to refer to the counterparts of discourse particles in the word classes of focus adverbs and focus particles.

[3] We will use the categorial term 'discourse particles' in this paper and not the alternative term 'modal particles'. Note that although some have pointed out terminological distinctions and confusion (e.g. Abraham 2017), most of the literature on this topic uses the terms interchangeably. The reason for our choice is that although discourse particles are sometimes synonymous with 
Before introducing the relevant data in the following section, we would like to add a cautionary note on what we can and cannot (or will not) provide in this paper that compares focus-marker with discourse-particle readings of certain elements. We will provide evidence (and analyses) for the claim that the semantic contribution in present-day Catalan of some focus markers is rather a discourse-particle interpretation-but we will not look into the diachronic connections between those readings. Such a historical investigation is beyond the scope of our paper. It is controversial to what extent the different readings of these elements can be historically derived from each other, and, if so, which reading is older (see Mosegaard Hansen \& Strudsholm 2008, Mosegaard Hansen 2018 on possible historical scenarios in Romance). Our goal is more modest: We first want to establish (by means of formal semantic tools and cross-linguistic observations) that there are discourse-particle interpretations of focus markers in Catalan in the first place. With these qualifications in mind, let us now turn to the two cases that to our mind are particularly interesting in this regard.

\section{The Catalan particles també And PRecisament}

\subsection{The additive focus particle tambe and the expression of negative attitude}

Like many other languages, Catalan features an inventory of additives (for additive particles in a general cross-linguistic perspective, see Forker 2016 and König 2017). In what follows, we will restrict ourselves to the additive particle també because in this case, as we will argue, we also observe a reading that is reminiscent of cases in other languages where additive particles can acquire a discourse-particle reading.

Additive particles presuppose that what is predicated of the focused constituent also holds for at least one alternative of such constituent (e.g. Karttunen \& Peters 1979; Krifka 1998). In Catalan, focused constituents occupy the last position of the matrix clause (Vallduví 1992). In (1a), també associates with the object and it presupposes that Núria plays some other instrument. In contrast, in (1b) the additive particle associates with the subject, which here appears postverbally, and it presupposes that someone other than Núria plays the piano.

modal elements such as higher adverbs, they should not be confused with these alternative devices and, syntactically speaking, should be represented in a different functional domain than what has been proposed by Cinque (1999) for modal adverbs. This point is worth noting because discourse particles cross-linguistically indeed express very similar meanings when compared to alternative modal expressions - be it in the epistemic (e.g. Giannakidou \& Mari 2018) or in the evidential domain (e.g. Murray 2017). However, there are crucial differences when it comes to their scopetaking behavior and this is why they cannot be the heads of the modal projections that were described by Cinque (1999) for adverbs, as one might be tempted to think. Given all the differences observed between alternative modal expressions and discourse particles in the current literature (e.g. Zimmermann 2011, Grosz to appear, and many others), we therefore prefer to use the term 'discourse' (instead of 'modal') particle'. 


\section{(1) (a) La Núria també toca [el piano]. the Núria too plays the piano \\ (b) També toca el piano [la Núria]. too plays the piano the Núria 'Núria plays the piano, too.'}

As has been shown extensively for English too, additive particles such as també feature anaphoric requirements, which can be analyzed as presuppositional anaphoras. Consider prominent examples like the following (Kripke 2009: 373):

(2) SAM is having dinner in New York tonight, too.

Kripke (2009) has pointed out that too has an anaphoric requirement that when one uses the particle too, one refers to information that is present in what Kripke calls the 'active context' (see also Ruys 2015 for recent discussion). The type of presuppositional anaphora associated with additive particles requires that it must be salient in the context that a person other than Sam is having dinner in New York. Crucially, as Kripke (2009) argues, although one can reasonably and safely assume that many people are having dinner in New York on any given night, an account merely proposing an existential presupposition would not be able to explain why (2) would be infelicitous without a salient alternative to the individual Sam in the active context.

Observe now that the Catalan particle també has discourse uses where it does not convey additivity and the respective presuppositional anaphoras mentioned above; rather, també in these cases adds an expressive meaning to the utterance in the sense of Potts (2007a). We will detail this meaning contribution in Section 3 below, but for now consider the following key example from Torrent (2011: 106):

(3) Tu també, fas cada cosa! you too do each thing 'The things you do!'

Example (3) does not convey that the addressee does something other than what is predicated in the sentence, but rather the speaker is expressing a negative emotion towards the actions of the addressee. The particle tambe in this expressive use frequently associates with sentence exclamations like (3) or wh-exclamatives such as (4); here, the speaker feels sorry for the addressee's bad luck.

(4) Quina mala sort has tingut també!

what bad luck has had too

'What bad luck you had!'

In contrast, this particle use of tambe is not felicitous when the speaker is not expressing negative surprise towards the proposition. In (5), també can only be interpreted as an additive particle: It is presupposed that other than having good 
luck, the addressee did something else (worked really hard to achieve something, for instance).

(5) Quina bona sort has tingut també!

what good luck has had too

'Also, what good luck you had!'

As already mentioned above, també often occurs not only in proper exclamatives (i.e. wh-exclamatives, see (4) above) but also in declarative clauses that can be characterized as sentence exclamations (according to Rett's (2011) terminology), such as (6):

(6) També tindria nassos que ens despatxessis!

too had noses that us fire

'It would be really unfair if you would fire us!'

In $w h$-exclamatives like (7), també can modify a DP (very often a pronoun), and either precede or follow the exclamative; in both cases, we witness a clear prosodic break:

(7) (a) $\mathrm{Tu}$ també, quines tonteries que fas!

you too which nonsense that do

'The nonsense you do!'

(b) Quines tonteries que fas, tu també!

The particle també can also appear without a DP/pronoun, and in this case, there is a clear preference for using it clause-finally, where it takes scope over the whole proposition:

(8) (a) Quines tonteries que fas, també!

(b) ?També, quines tonteries que fas!

In sentence exclamations like (6) above, we observe similar placement options and preferences. In particular, també in its non-additive use occurs at the edge of the respective declarative clause: either clause-initially or clause-finally when modifying a pronoun, as in (9), or preferably clause-finally when it modifies the whole proposition, as in (10).

(9) (a) $\mathrm{Tu}$ també, tindria nassos que ens despatxessis! you too had noses that us fire

(b) Tindria nassos que ens despatxessis, tu també! had noses that us fire you too

'It would be really unfair if you would fire us!'

(10) (a) També tindria nassos que ens despatxessis!

(b) ?Tindria nassos que ens despatxessis també! 
In the latter case, there is no prosodic break between també and the proposition it modifies.

Although it is not our goal in this paper to analyze the syntax of this use of també, the data above seem to indicate that its base position is somewhere in the periphery of the clause. This is clearly evidenced by examples where the discourse and the additive particle també co-occur in one utterance, such as (11) - also again showing that we indeed can observe two very different meanings of també.

(11) També tindria nassos que també ens despatxessin a nosaltres! too had noses that too us fire to us 'It would be really unfair if they would also fire us!'

In those cases, the clause-medial occurrence of també can only receive the additive reading, while the non-additive version of també appears sentence-initially.

All in all, and regarding its syntax, Catalan non-additive també thus patterns with peripheral occurrences of discourse particles in Asian languages such as Cantonese (Matthews \& Yip 2013), Mandarin (Paul \& Pan 2017), and Japanese (Kuwabara 2013), and with the placement of discourse particles at the outer edge of the clause that has been documented for the Indo-European language Romanian (Coniglio \& Zegrean 2012). Syntactically speaking, Catalan també seems to be another case where the clausal left periphery encodes discourse-oriented and/or attitudinal readings of an utterance.

Finally, and turning to its semantic properties again, we have already observed above that també in its non-additive use expresses that the speaker has a negative attitude towards the proposition $p$. For ease of reference, let us therefore call this use of també 'també $e_{\mathrm{EXPRESSIVE}}$ ' and distinguish it from the focus marker 'també $e_{\mathrm{ADDITIVE}}$ '. Crucially, tamb $e_{\text {EXPRESSIVE }}$ is used in exclamation speech acts (as illustrated above), whose central feature is that they convey a presupposition of subjective veridicality such that the speaker believes that the propositional content is true (see Grimshaw 1979, Zanuttini \& Portner 2003, Abels 2010 for alternative accounts about the nature of this presupposition). ${ }^{4}$ In other words, també $e_{\text {EXPRESSIVE }}$ and its expression of negative attitude requires that it has to be in the Common Ground that $p$ is true. To see this, note that utterances featuring també $e_{\text {EXPRESSIVE }}$ cannot be used as answers to narrow-focus questions (12B), showing that they cannot provide the relevant new information.

[4] We are not using the common term 'factivity presupposition' here because we adopt the view recently argued for by Trotzke \& Giannakidou (2019) that this meaning component is not a presupposition of factivity but of subjective veridicality, i.e. exclamations rely on the speaker's belief that the propositional content is true and do not require that it is actually true. According to this approach, exclamations presuppose belief of truth about $p$ (veridicality) by the speaker (see also Section 3.2 below). Trotzke \& Giannakidou's (2019) account is based on recent experimental work that has shown that $w h$-exclamatives and declarative sentence exclamations behave exactly alike regarding their descriptive/presupposed content (Trotzke 2019), and we submit that this is exactly what we need in order to explain the distribution of també $e_{\text {EXPRESSIVE }}$, which cannot only occur in $w h$-exclamatives, but also in declarative sentence exclamations (see examples above). 


\section{A: Què compra?}

'What is he buying?'

B: \#Ell també, quins llibres que compra!

he too which books that buys

'The books he buys! (How bad!)'

However, we observe that the presupposition that the propositional content is true is not due to the use of també $e_{\text {EXPRESSIVE }}$, but rather is a feature of the exclamation speech act itself. That is, the utterance without tambe $e_{\text {EXPRESSIVE }}$ is as bad as (12B) above when used as an answer to a question:
A: Què compra?
'What is he buying?'
B: \#Quins llibres que compra!
which books that buys
'The books he buys!'

We thus hypothesize that while the negative attitude in (12B) is clearly due to tamb $e_{\text {EXPRESSIVE }}$, the presupposition that the speaker believes that the propositional content is true is not. Crucially, as we will argue in this paper, the expression of negative attitude is not the only meaning component conveyed by també $e_{\text {EXPRESSIVE }}$. In particular, we claim that there is another aspect that can be modelled according to 'argumentative scales' (see Winterstein 2011, Winterstein et al. 2018 and Section 3 below); these scales involve a consideration of the goal a speaker is aiming at in a discourse. In the case of tambe $e_{\text {EXPRESSIVE }}$, the speaker is not only expressing his negative attitude, but rather the utterance containing també $e_{\text {EXPRESIVE }}$ is interpreted as arguing for the goal 'a negative attitude can be considered justified by both speaker and addressee'. We will turn to this point in detail in Section 3, but for now let us briefly illustrate this point.

Example (13) below again contains a minimal pair of an exclamation with and without també $e_{\text {EXPRESSIVE. }}$.

(13) A: Què me'n pots dir del nou concerge?

'What can you tell me about the new doorkeeper?'
B: És ben despistat, aquest noi! Ahir es va deixar is so absent.minded this guy yesterday CL PST left la porta oberta.

the door open

'This guy is so absent-minded! Yesterday he left the door open.'
B': \#És ben despistat, aquest noi també! Ahir es va is so absent-minded this guy too yesterday CL PST deixar la porta oberta. left the door open

The version without també $e_{\text {EXPRESSIVE }}(13 \mathrm{~B})$ is a felicitous response to the question posed by Speaker A, while the version with també $e_{\text {EXPRESSIVE }}\left(13 \mathrm{~B}^{\prime}\right)$ is pragmatically 
deviant since in this case it is not clear in this broad-focus context whether there is any reason to hold a negative attitude. Once it is salient in the context for both speaker and addressee why one could have a negative attitude, the utterance becomes fully acceptable, as can be seen in (14):

(14) A: El nou concerge ahir es va deixar la porta oberta. 'Yesterday the new doorkeeper left the door open.'

B: És ben despistat, aquest noi també! is so absent-minded this guy too 'This guy is so absent-minded!'

These examples indicate that both speaker and addressee must be able to relate to the speaker's negative attitude in the sense that this attitude is not without cause in

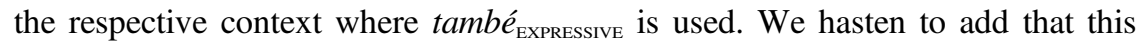
interpretation component of també $e_{\text {EXPRESSIVE }}$ does not mean that the addressee also has to share the negative attitude expressed by the speaker. The addressee merely has to able to see that this negative attitude can be considered justified - in this way, també contributes a meaning that could also be considered evidential. Consider the following example:

A: Potser hauré de despatxar algú.

'I may have to fire someone.'

B: També tindria nassos que ens despatxessis! too had noses that us fired 'It would be really unfair if you would fire us!'

In (15), it is clear that Speaker A does not need to share the negative attitude by Speaker B towards the surprising fact that Speaker B (and colleagues) will maybe be fired. Nevertheless, Speaker B can use també $e_{\text {EXPRESSIVE }}$ in such a context because Speaker A is aware of the fact that Speaker B's negative attitude is justified in the given context of surprisingly firing Speaker B (and colleagues).

All in all, the data discussed in this section have already indicated the following three meaning contributions that characterize the non-additive use of també, which we will analyze and thus further detail in Section 3 below:

- It is presupposed that the propositional content is true (not due to també $e_{\text {EXPRES- }}$ SIvE, but to its occurrence in exclamations).

- The speaker (and not necessarily also the addressee) holds a negative attitude.

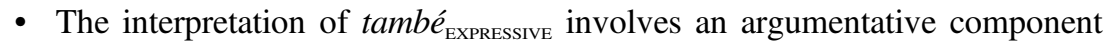
because the use of també $e_{\text {EXPRESSIVE }}$ is interpreted as arguing for the goal 'a negative attitude can be considered justified by both speaker and addressee'.

Given that també $e_{\text {EXPRESSIVE }}$ thus contributes a negative attitude component, we can raise the question of what type of meaning this attitudinal component is. We hypothesize that it belongs to the class of conventional implicatures (CIs) just like other expressive items. One of the main tests to characterize expressive items is their 


\section{CATALAN FOCUS MARKERS AS DISCOURSE PARTICLES}

behavior when embedded. According to Potts (2007a), expressive items are nondisplaceable; that is, they predicate something about the utterance situation and cannot be used to talk about past events or express possibilities and cannot be semantically embedded (even if they are syntactically embedded).

For instance, the English expressive bastard cannot be interpreted in the scope of negation, as shown by the incongruence of the second sentence in (16): Negation only takes scope over the at-issue meaning (the proposition that Kresge is late for work) and does not apply to the attitude conveyed by bastard, which is left untouched (example from Potts 2007a: 169):

(16) That bastard Kresge isn't late for work (\# He's a good guy).

We can apply the same kind of test to també $e_{\text {EXPRESSIVE }}$. If the negative attitude conveyed by també $e_{\text {EXPRESSIVE }}$ were truth-conditional, we would expect that it could be semantically embedded under negation, and $(17 \mathrm{a}, \mathrm{b})$ should have a sensible reading, i.e. it should be interpreted as conveying that it is not the case that the speaker has a negative attitude towards the addressee (not) being organized. However, this is not a possible reading of (17), and this is why (17b) is incoherent.
(a) No es pot dir que siguis gaire ordenat també! no CL can say that be very organized too
'It cannot be said that you are very tidy!'
(b) \#M' encanta que siguis així.
me please that are like.this
'I love it that you are like this.'
$\left(b^{\prime}\right)$ Estic fart del teu desordre. am sick of.the your mess 'I am sick of your mess.'

In contrast, $\left(17 \mathrm{a}, \mathrm{b}^{\prime}\right)$ is coherent since in (17a) també EXPRESSIVE is not semantically embedded under negation and conveys that the speaker has a negative attitude towards the fact that (it is not possible to say) the addressee is organized. We take the unacceptability of $(17 \mathrm{a}, \mathrm{b})$ to show that the negative attitude of també EXPRESSIVE cannot be truth-conditional. It is, however, compatible with the attitudinal component being either a presupposition or a CI. To distinguish between the two possibilities, a test using the attitude verb 'believe' can be applied to our Catalan particle també $e_{\text {EXPRESSIVE }}$.

Presuppositions under 'believe' need not project, while CIs do project, as shown by the following examples from Tonhauser et al. (2013). The English example (18a) does not presuppose that Bill used to smoke (or that the speaker believes that Bill used to smoke), but that Jane believes Bill used to smoke. In Tonhauser et al.'s (2013) terminology, there is a Local Effect: The projective content of stopped smoking contributes to the local context of the embedding verb. In contrast, CIs project under believe, as shown in (18b). In (18b), the CI conveyed by the appositive noun phrase (i.e. the content that Bill is Sue's cousin) projects and is attributed to the 
speaker and not to the subject of believe, who actually thinks that Bill is Sue's brother).

(18) (a) Jane believes that Bill has stopped smoking (although he's actually never been a smoker).

(b) Jane believes that Bill, who is Sue's cousin, is Sue's brother.

Here, there is no Local Effect. If there were, the content of the appositive would contribute to the local context created by believe and the whole sentence would be contradictory (since two beliefs that cannot be true at the same time would be attributed to Jane).

Crucially, the particle també $e_{\text {EXPREssive }}$ displays the same behavior. Look at the following example:
(a) La Maria creu que el Joan no aprovarà també! the Maria believes that the Joan not pass too 'Maria believes that Joan will not pass!'
(b) Estic fart que sigui tan negativa. am sick that be so negative 'I am sick of her being so negative.'
(c) \#A mi, m'és igual. to me clbe same 'I don't care.'

In (19a), the negative attitude conveyed by també EXPRESSIVE is really 'anchored' to the speech act of the speaker and can thus not be about the subject's (= Maria's) attitude, there is no Local Effect. This can be seen in the acceptable follow-up in (19b): The negative attitude is anchored to the speaker and not to Maria. If the negative attitude of també $e_{\text {EXPRESSIVE }}$ in (19) had a Local Effect, we would expect a coherent meaning in which Mary has a negative attitude towards Joan's not passing the exam which is not shared by the speaker. However, this reading is impossible, and the follow-up in (19c) is not coherent, since the negative attitude conveyed by també $e_{\text {EXPRESSIVE }}$ is attributed to the speaker.

We can thus conclude that the expression of negative attitude is CI content, and together with its other meaning components (i.e. the presupposition that the propositional content is true and the argumentative scale), we will analyze this content in detail in Section 3.2 below. We will connect our findings to what we observe in the context of another Catalan particle: precisament (see the following Section 2.2). Among other things, we will show that while també $e_{\text {EXPREsSIvE }}$ conventionally implicates the speaker's negative attitude, precisament conveys an emotionally 'neutral' meaning. Interestingly, in other languages it is exactly the other

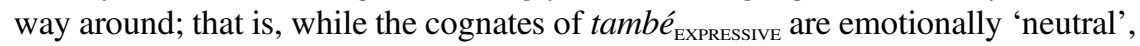
the cognates of precisament feature an expression of negative attitude. We will turn to these cross-linguistic comparisons in our final Section 4. But now let us take a detailed look at the other interesting particle: Catalan precisament. 


\subsection{The focus adverb precisament and the emphatic expression of identity}

In this section, we will show that the Catalan adverb precisament 'precisely' has a variety of interpretations ranging from denoting manner to expressing discourse meanings. It can function as a VP-adverb with a manner interpretation, paraphrasable as 'with precision', as shown in (20). In contrast, it cannot be used as a degree adverb, meaning 'exactly', unlike its counterpart in English, as shown in (21).

(20) Han desenvolupat un mètode per mesurar més precisament have developed a method to measure more precisely la distància entre galàxies.

the distance between galaxies

'They developed a method to measure more precisely the distance between galaxies.'

(21) La pel-lícula va durar exactament/*precisament 115 minuts. the film PST last exactly/precisely 115 minutes 'The film lasted exactly/precisely 115 minutes.'

A different use of precisament is as a focus adverb. As already mentioned above, in Catalan focused constituents occupy the last position of the matrix clause (see Vallduví 1992). As can be seen in (22), precisament associates with the constituent in focus: la Maria in (22a) and el piano in (22b).

(22) (a) Ha tocat el piano precisament [la Maria].

has played the piano precisely the Mary

'Precisely Mary played the piano.'

(b) La Maria ha tocat precisament [el piano]. the Mary has played precisely the piano 'Mary played precisely the piano.'

The focus-sensitivity of precisament can be demonstrated by the rather trivial fact that the two sentences in (22) cannot be used interchangeably. (22a), but not (22b), would be acceptable as a follow-up to (23a), while only (22b), and not (22a), would be fine in (23b):

(23) (a) Of all my students, Mary is the least likely to choose the piano as an instrument to play but today... (could be followed up by (22a))

(b) Of all the instruments, the piano is the least likely to be chosen by Mary, but today... (could be followed up by (22b))

In its focus use, precisament often highlights the identity between two events or entities; this identity, which in its temporal reading can be conceptualized as a 'coincidence', can be temporal (24), locative (25), or causal (26), similar to the idiomatic expression 'of all N' in English (e.g. Krifka 1995: 227-229): 
(24) Han arribat precisament quan ella marxava. have arrived precisely when she left 'They arrived precisely when she was leaving.'

(25) Va morir precisament a l' habitació on havia nascut. PST died precisely in the room where had born 'He died precisely in the room where he was born.'

(26) Més tard, aquest cardenal, ja molt vell - i precisament more late this cardinal already very old and precisely perquè ja és vell-, és elegit Papa. because already is old is elected Pope 'Later this cardinal already very old - and precisely because he is already old - is elected Pope.'

Let us look at the semantic import of this focus marker in more detail without going into the formal details at this point of the paper. Catalan precisament conveys that the expression in focus is also an argument in another salient proposition. For instance, in (24) the temporal argument of the event 'He arrived at $t$ ' has the same value of the temporal value of the event 'She left at $t$ '. The expression of this identity (in the temporal case: of this 'coincidence') often also conveys that it is unexpected; what precisament is thus doing is marking 'a conflicting identity' between the two arguments (see König 1991 on a relevant notion of 'conflicting identity'). In other words, it is not usually the case that the arguments of these two propositions have the same identity. Accordingly, by using precisament, the speaker conveys that such an identity is noteworthy in the current discourse context. This can be seen even more clearly in some naturally-occurring examples retrieved from the web. ${ }^{5}$

In (27), the adverb highlights that there is a noteworthy identity in that one character is seeking solace in another one despite having lived apart for many years.

(27) Que estrany que se li fa, que ara li demani consol a ell, how strange that $\mathrm{CL}$ him does that now him asks solace to him precisament, després de tants anys de viure allunyats l' un precisely after of so years of live far the one de l' altre.

of the other

'It feels so strange that he seeks solace in him, of all people, after so many years of having lived apart.'

(https://www.ara.cat/societat/Fantasmes-dhospital_0_1344465601.html)

In (28), the speaker points out that it is ironic that Turull will be the person to reconstruct the self-government, given that he greatly contributed to its destruction.

[5] The sources of examples taken from the internet are indicated in parentheses after the examples. 
In this case too, the identity of the relevant person is noteworthy (because in this case it is unexpected), and precisament is expressing this noteworthiness.

(28) Turull haurà de reconstruir l' autogovern. i ho haurà Turull must of reconstruct the self.government and it must de fer ell, precisament, que tant va fer per carregar-se'l. of do him precisely that so PST do to destroy-it

'Turull will need to reconstruct the self-government. And it will be him, of all people, who did so much to destroy it, the one who will need to do it.' (https://www.rac1.cat/programes/el-mon/20180322/441816937275/lhereu-depujol.html)

Finally, (29) can be understood as a reply to an addressee who is criticizing subsidies even though he is a beneficiary of such subsidies; this can be considered another case of an identity that is worth noting.

(29) I tu, precisament tu! parles de "subvencions"? Quina barra! and you precisely you talk of subsidies which jaw

'And you, of all people, talk about subsidies? What a cheek! (https://dbalears.cat/opinio/2016/11/07/295596/quintacolumna-esta-mal-pler.html)

Given the above examples and paraphrases, the import of precisament seems somewhat reminiscent of scalar particles like even in English, at least in those cases where the emphatic assertion of an identity is embedded in a context of conflicting expectations and thus connected to a scale of likelihood (for an overview of further lexical means to convey scalar notions of emphasis, see Beltrama \& Trotzke 2019). However, precisament, in contrast to the additive even, does not presuppose that the predication holds for some other alternative. Crucially, in the current literature it is pointed out that the only three languages that feature particles expressing similar interpretations to Catalan precisament are German (ausgerechnet), Dutch (uitgerekend), and Hebrew (davka/split); see König (2017). If we take into account data like the above, we can now add Catalan to the class of languages that convey this kind of meaning by means of a single focus-marking element. ${ }^{6}$

Now, precisament also has another discourse use, as shown in examples (30) and (31) below, in which its emphatic-identity reading refers to the respective sequence of speech acts in a dialogue. Here, precisament can serve to signal that there is a noteworthy coincidence between the previous utterance of the addressee and the

[6] Note also that German ausgerechnet and Dutch uitgerekend literally mean 'calculated' (past participle of 'to calculate'), and Hebrew דווקא can be translated as 'precisely'. This all might suggest that the discourse reading we illustrated above might be cross-linguistically connected to 'expressions of precision', as it were (i.e. precisament and 'calculated') - an interesting parallel and data point in its own right. 
current utterance of the speaker, similar to the expressions 'funny you should ask/say this' in English.
A: Saps com està la Maria?
'Do you know how Maria is doing?'
B: Precisament, ahir me la vaig trovar pel carrer. precisely yesterday CL her PST find for.the street '(Funny you should ask this,) I actually bumped into her on the street yesterday.'

(31) A: El que més em preocupa és el llenguatge que el pare fa servir amb la mainada.

'What worries me the most is the language that the father uses with the children.'

B: Precisament la Maria i jo n' havíem estat parlant, precisely the Maria and I PVE had been talking d' aquesta quiestió, fa unes setmanes. of this issue make ones weeks

'(Funny you should say this,) Maria and I were actually talking about this issue a few weeks ago.'

Specifically, in (30) the adverb signals that the speaker has a relevant answer for the addressee's question given that he saw Mary yesterday. In (31), precisament signals that the speaker has something relevant to say about the issue raised by the addressee, and the fact that he has just talked about that particular issue with another person can be considered noteworthy. In these cases, the meaning of precisament is very similar to the use previously discussed, but with an important difference: It scopes over the whole speech act performed by the addressee in the preceding context. That is, in $(31 \mathrm{~B})$ precisament does not emphasize that the speaker's current speech act is identical to something what is said (i.e. there may not be anything surprising in uttering that he saw Mary yesterday), but that the previous question is surprisingly relevant for the speaker. ${ }^{7}$

Let us take stock. The focus adverb precisament features anaphoric requirements in the form of specific presuppositions that must be met. Specifically, the use of precisament emphasizes the identity (or in many of our cases: the coincidence) of two values or arguments in two different propositions or of two consecutive speech acts. Note that some of our examples might suggest that the semantics of precisament contains a negative evaluative component. For instance, in (29) above the inference is that the addressee should not be talking about subsidies. However, this evaluative component is not always present; observe examples like the following:

[7] As noted by an anonymous $J L$ referee, the behavior of German gerade is reminiscent of precisament. However, gerade is restricted to contexts in which the utterance time of the previous speech act and the event time are close, while precisament is not subject to this restriction. Thus, gerade would be acceptable in $(30 \mathrm{~B})$, where the event time is denoted by 'yesterday', but not in (31B), where the event time is denoted by 'a few weeks ago'. 


\section{CATALAN FOCUS MARKERS AS DISCOURSE PARTICLES}

(32) Jugar és un dret! Precisament això han fet els infants de play is a right precisely this have done the children of Gràcia per celebrar el Dia del Joc. Gràcia to celebrate the Day of.the Play 'Play is a right! This is precisely what children in Gràcia have done to celebrate World Play Day.'

(https://twitter.com/barcelona_cat/status/736615800396599296)

We will thus consider this aspect of interpretation a conversational implicature and will not integrate it in our analysis. As we will also argue below, precisament is thus different from $t^{a m b} \dot{e}_{\text {EXPRESSIVE }}$ : In the case of també $e_{\text {EXPRESSIVE }}$, the evaluative component is indeed part of the lexical meaning and thus not triggered by a conversational implicature.

In sum, the data discussed in this section have demonstrated the following meaning contributions that characterize the Catalan focus marker precisament and that we will detail in Section 3 below:

- It conveys that there is (at least) an alternative $q$ to the proposition $p$ such that $q$ it is not true.

- It emphasizes that there is either a value or an argument that is identical in two different propositions.

- Emphasizing this identity is used for expressing the overall interpretative effect that this identity is noteworthy.

Given all these illustrations of both Catalan també $\dot{e}_{\mathrm{EXPRESSIVE}}$ and precisament, we are now in a position to turn to a formal analysis of these elements.

\section{A formal analysis for Catalan discourse particles: A probabilistic- ARGUMENTATION ACCOUNT}

\subsection{The probabilistic argumentative framework}

To account for the discourse meanings of both també $e_{\text {EXPRESSIVE }}$ and precisament in Sections 3.2 and 3.3 below, we will build on some previous work by Winterstein (2011, 2012) and Winterstein et al. (2018), who use probabilistic semantics, following Merin (1999), to capture the notion of argumentation (see Anscombre \& Ducrot 1977, 1983) when investigating particle elements in different languages. Let us therefore briefly sketch some basics about this formal framework.

According to Merin (1999), argumentation theory postulates that every utterance in a discourse is oriented towards an argumentative goal. In other words, speakers always use utterances to speak 'to a point'. If an utterance argues for a goal, its orientation is positive regarding this goal; if it argues against it, it is negative regarding this goal. This notion of orientation is useful to explain a variety of discourse phenomena. For instance, observe the acceptability of an answer like in (33B); see Winterstein (2012) for a similar discussion. 

A: Is the dinner ready?
B: Yes, almost.

The answer in (33B) is felicitous, although it is a logical contradiction: If the dinner is almost ready, it is not ready. Although 'almost $p$ ' entails 'not $p$ ', it argues FOR the same set of goals as $p$ does (i.e. it preserves the argumentative profile of $p$ and its orientation is positive); therefore, it is compatible with a positive answer; see Jayez \& Tovena (2008) for more extensive discussion.

Merin (1999) casts argumentation as a probabilistic relation, such that a proposition $p$ is an argument for a goal $H$ iff asserting $p$ raises the probability of $H$ in the epistemic model, or, more formally, $\mathrm{P}(\mathrm{H} \mid \mathrm{p})>\mathrm{P}(\mathrm{H})$, where $P$ is a probability measure. In addition, the strength of an argument can be captured by means of a probabilistic relevance function $r$ such that $p$ argues for $H$ iff $\mathrm{r}(\mathrm{p}, \mathrm{H})>0$.

This framework allows us to identify and account for the fact that some linguistic expressions are intrinsically argumentative, such as almost as illustrated above. Another well-known case is the connective but. In a sentence with but, the first conjunct argues for a goal, the second argues against it, the second one being more relevant than the first one. This is formalized in (34); see Winterstein (2012: 1875):

$$
\begin{aligned}
& \text { (a) } \mathrm{r}(\mathrm{p}, \mathrm{H})>0 \text { and } \mathrm{r}(\mathrm{q}, \neg \mathrm{H})>0 \\
& \text { (b) } \mathrm{r}(\mathrm{q}, \neg \mathrm{H})>\mathrm{r}(\mathrm{p}, \mathrm{H})
\end{aligned}
$$

According to Winterstein (2012), the constraint in (34b) is why (35a) is interpreted as arguing against the goal 'We should buy the ring', while (35b) argues against 'We should not buy the ring':

(35) (a) The ring is nice, but expensive.

(b) The ring is expensive, but nice.

Winterstein (2011) argues also that the additive focus particle too is subject to some argumentation constraints. In particular, he is concerned with the following contrast: ${ }^{8}$

(36) (a) For his breakfast, Lemmy had an apple. Ritchie only had a piece of fruit too.

(b) Lemmy did not solve all the problems. Ritchie solved some of them (\# too).

(36a) shows that the antecedent of the presupposition of too does not need to have been asserted, but it can be a conversational implicature of a previous sentence. In particular, the second sentence of (36a) presupposes that someone else had only a piece of fruit too, and this presupposition is satisfied by the conversational

[8] Let us hasten to add that the following data and their interpretation are not undisputed, as has been pointed out to us by an anonymous $J L$ referee. However, we share Winterstein's (2011) judgments and would therefore like to introduce the general idea based on those data and judgments. 
implicature of the first sentence (i.e. (36a) conversationally implicates that Lemmy didn't have anything else apart from apple). (36b) also presents an implicated antecedent for the presupposition of too: The second sentence presupposes that someone else solved some of the problems, while the first sentence implicates that Lemmy solved some of the problems. Still, the presence of too renders (36b) infelicitous. In order to account for the infelicity, Winterstein (2011:333) postulates the following constraint for the use of an additive particle like too:

\section{Co-orientation Condition}

$\mathrm{r}(\mathrm{p}, \mathrm{H})$ and $\mathrm{r}\left(\mathrm{C}^{\prime} \mathrm{Host}, \mathrm{H}\right)$ must carry the same sign (i.e. their orientation must be the same; either both of them are positive or both of them are negative), where

(i) CHost is the utterance from which the antecedent of the presupposition can be inferred, and

(ii) C'Host is CHost, but with the element associating with too replacing the relevant argument in CHost.

For the case in (36a), we then obtain the following: $p=$ Ritchie only had a piece of fruit; CHost $=$ Lemmy had an apple; $C$ 'Host $=$ Ritchie had an apple. If we take $H$ to be 'Ritchie only had a piece of fruit' (so equivalent to $p$ ), we can see that both $p$ and $C^{\prime} H o s t$ argue for it; that is, they both have a positive orientation. In other words, they satisfy the Co-orientation Condition. In contrast, for the example in (36b), we obtain the following: $p=$ 'Ritchie solved some of the problems'; $C H o s t=$ 'Lemmy did not solve all the problems'; C'Host = 'Ritchie did not solve all the problems'. Since negation changes the sign of the orientation, $p$ and $C^{\prime} H o s t$ will have opposite orientations ( $p$ argues for a goal $H$ and $C^{\prime} H o s t$ argues against it) and, therefore, the Co-orientation Condition is not satisfied. ${ }^{9}$ Note that the goal could be construed as equivalent to $p$, as we did in (36a), 'Ritchie solved some of the problems', or also more broadly, such as 'Ritchie did well in the math test'.

Let us now see how we can apply these insights from argumentation theory to the analysis of també $\dot{e}_{\mathrm{EXPRESSIVE}}$ (Section 3.2) and precisament (Section 3.3).

\subsection{A probabilistic argumentative analysis for Catalan també}

This section proposes an analysis for the two different interpretations of Catalan també (i.e. additive and non-additive, as illustrated in Section 2.1 above). The proposal is inspired by recent analyses of similar particles in other languages, in

[9] Note that it is possible for two utterances to have different polarities but the same orientation, as in the following example, provided by an anonymous $J L$ referee:

(i) Lemmy didn't show up, and Ritchie was absent, too.

In (i), C'Host is negated and $p$ is not. Still, the use of too is totally fine here because both $p$ and $C^{\prime} H o s t$ argue for a goal $H$ of the form 'Ritchie was absent/not present'. 
particular the analysis of the particle timl in Cantonese, which has both additive and mirative readings (see Winterstein et al. 2018), the analysis of the Japanese evaluative particle yokumo in McCready (2010), and the analysis of German discourse particles proposed by Gutzmann (2009). As will be shown shortly, també in both interpretations contributes meaning simultaneously at several dimensions of meaning: most notably, at the at-issue and the CI dimension (see Potts 2005).

In a nutshell, at-issue meanings contribute the assertion of the utterance, which can be embedded under semantic operators and can be denied by another participant in the conversation. ${ }^{10}$ In contrast, both CIs and presuppositions are harder to deny, and they project out of entailment-cancelling operators. The difference between presuppositions and CIs is, very roughly, that the former typically convey content shared in the Common Ground between speaker and hearer, whereas the latter contribute new information which is secondary to the main point (i.e. the assertion) that the speaker is making. We will treat both expressive meanings (needed for nonadditive també) and argumentative constraints (needed for both additive and nonadditive també) as CIs, following Winterstein et al. (2018) on this last point.

Given this conceptual background, we first analyze the focus particle també $e_{\mathrm{ADD}}$ TIVE. According to what we have explained above for the very similar English additive too, també $e_{\mathrm{ADDTTVE}}$ is an expression that simultaneously conveys at-issue and CI content. (38) represents its denotation, in which the '•' operator joins at-issue and CI meanings (Potts 2005, McCready 2010): ${ }^{11}$

$$
\begin{aligned}
\llbracket \text { tamb }_{\text {ADDITVE }} \rrbracket= & \lambda \mathrm{Q} \lambda \mathrm{x} .\{\exists \mathrm{y} \in \Psi(\mathrm{x}): \mathrm{y} \neq \mathrm{x}, \mathrm{Q}(\mathrm{y})\} \cdot \mathrm{Q}(\mathrm{x}) \bullet \lambda \mathrm{Q} \lambda \mathrm{x} . \text { co-oriented } \\
& \left(\mathrm{Q}(\mathrm{x}), \mathrm{Q}(\mathrm{y})^{\prime}\right),
\end{aligned}
$$

in which

- $\mathrm{x}$ is the associate of també

- $\mathrm{Q}$ is the scope of també, the abstraction such that $\mathrm{Q}(\mathrm{x})=$ $\mathrm{p}$, where $\mathrm{p}$ is the proposition també combines with

- $\Psi(x)$ is the set of accessible alternatives of $x$

- $\mathrm{Q}(\mathrm{y})$ ' is akin to 'C'Host' in Winterstein (2011); i.e. the antecedent of the presupposition, but with the element associating with too replacing the relevant argument in $\mathrm{Q}(\mathrm{y})$

- The function 'co-oriented(p,q)' is defined as $\mathrm{r}(\mathrm{p}, \mathrm{H})$ and $\mathrm{r}(\mathrm{q}, \mathrm{H})$ having the same orientation: Either they are both positive or they are both negative.

[10] It is worth noting that here and in what follows, we use the term 'embedded' to refer to semantic embedding under certain entailment-cancelling operators. That is, we are concerned with the difference between projective and non-projective content - a difference which has traditionally been used as a diagnostic for presuppositions. More recently, however, many other expressions have been investigated from this perspective too (e.g. appositives and expressives); see Simons et al. (2010) and Tonhauser et al. (2013) for two recent overviews and comprehensive accounts and our discussion in Section 3.2 below.

[11] For logic details of this type of 'multidimensional meaning' and detailed rules of proof, see McCready (2010: 13-15) and Gutzmann (2015) on hybrid semantics more generally. 
In other words, the focus marker també $\dot{\mathrm{ADDITIVE}}$ conveys the following three interpretative components:

(i) the assertion of $\mathrm{Q}(\mathrm{x})$, that is, of the proposition $p$

(ii) the presupposition that $\mathrm{Q}$ also holds of an alternative to $\mathrm{x}^{12}$

(iii) the $\mathrm{CI}$ that $\mathrm{Q}(\mathrm{x})$ and $\mathrm{Q}(\mathrm{y})$ ' are co-oriented towards a goal $H$

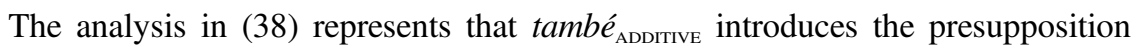
(ii) and the $\mathrm{CI}$ in (iii), leaving its assertive at-issue content (i) unchanged.

In contrast to the additive focus-marker interpretation in (38), we propose that the non-additive reading of també with its expression of negative attitude does not involve a presupposition nor asserted content. Rather, it only involves CI content. We have already illustrated in Section 2.1 above why we postulate that its contributions are indeed CI contents only, and not presuppositions. The remaining question now is what semantic type exactly can be assigned to this content, and we believe that the answer to this question crucially relies on how we deal with the utterances també $\dot{E}_{\text {EXPRESSIVE }}$ occurs in: exclamations.

In Section 2.1 we have already indicated that també $\dot{e}_{\text {EPRRESSIVE }}$ can not only occur in $w h$-exclamatives, but also in exclamation speech acts more generally (e.g. also in declarative sentence exclamations like 'This guy is so absent-minded!' etc., see Catalan examples above). Given this situation, we follow Trotzke \& Giannakidou (2019) who unify the semantics of a variety of different exclamation types by claiming that the emotive stance of exclamation speech acts is actually an emotive assertion akin to assertions of sentences containing emotive predicates such as be amazed, be surprised in English, and that exclamation speech acts and such assertions have very similar truth conditions and presuppositions. We cannot discuss the details of their approach here, but let us briefly sketch how this works semantically.

Building on Giannakidou \& Mari's (2020) proposal for emotive predicates, Trotzke \& Giannakidou (2019) assume that there is a set of worlds $W$ ordered by the emotion (sentiment) $S$. $W$ is partitioned into two equivalence classes of worlds. One is the set of worlds in which the attitude holder has the emotion and $p$ is true. The other one is the set of worlds in which the attitude holder does not have the

[12] As acknowledged in Winterstein (2011), too can appear in cases without lexical identity. The same is true for Catalan també, as shown in (i):

(i) Are Rita and Jofre old enough to drive?

La Rita ja té el carnet i el Jofre també té més de 18 anys.

'Rita has a driver's license and Jofre is over 18 too.'

The additive també is licensed even if the two predicates ('have a driving license' and 'be over 18') are not the same and merely connected by the fact that having a driver's license entails that Rita is over 18. Given this situation, the two conjoins make the same point at the argumentative level: i.e. both being over 18 and having a driving license argue for someone being old enough to drive. We thank an anonymous $J L$ referee for raising this point. 


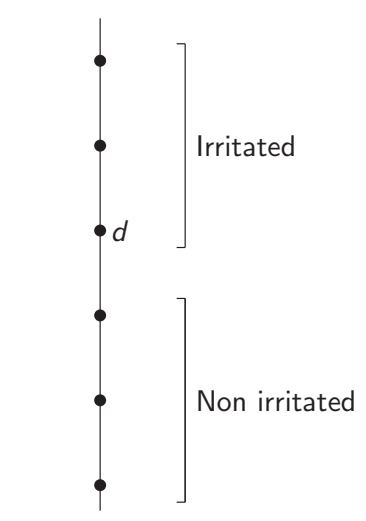

Degree scales

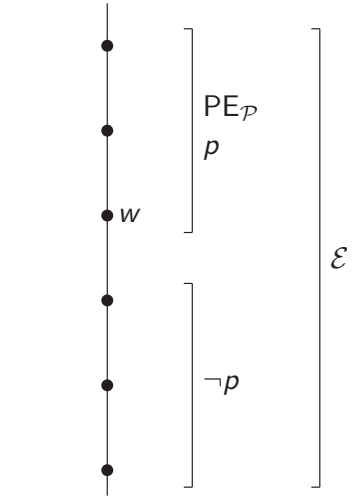

World ordering

Figure 1

Emotion as a non-veridical space, from Giannakidou \& Mari (2020: 243).

Note: $d=$ degree, $\mathrm{w}=$ world, $p=$ proposition, $\varepsilon=$ emotive space, $\mathrm{PE} p=$ Positive-Extent-worlds for $p$

emotion and $p$ is false. This partitioning allows us to define Positive-Extent-worlds (PE) for $p$; $\varepsilon$ refers to the emotive space:

(39) $\mathrm{PE}_{\mathrm{P}}=\left\{\mathrm{w}^{\prime} \in \varepsilon_{\mathrm{P}}: \mathrm{w}^{\prime}\right.$ where the propositions in $\mathrm{P}$ are true $\}$

The set $\mathrm{P}$ is the singleton set $\{\mathrm{p}\}$. Accordingly, $\mathrm{PE}_{\mathrm{P}}$ contains all the worlds in which $p$ is true. In $\mathrm{PE}_{\mathrm{P}}$, the speaker has sentiment $S$. But not all worlds in $\varepsilon$ are PE worlds for $p ; \varepsilon$ only partially supports $p$. $\mathrm{PE}_{\mathrm{P}}$ is a subset of $\varepsilon$. The complement of $\mathrm{PE}_{\mathrm{P}}$ contains $\neg \mathrm{p}$ worlds. The semantics proposed here is reminiscent of the 'Best ordering' used for modals (Portner 2009: Chapter 4); it is indeed a similar ordering function, only according to the present approach, the ordering source merely contains $p$. Figure 1 summarizes this constellation of worlds, based on the emotion 'irritated', which is gradable like all emotive attitudes are.

Given this semantic background, we can now formulate the denotation of an exclamation (EX), where $\operatorname{Dox}(s)$ is the belief state of the speaker, $\varepsilon$ is the emotive space, and $P E$ refers to Positive-Extent-worlds for $p$ (for more details, see Trotzke \& Giannakidou 2019):

(40) $\llbracket \mathrm{EX}(\mathrm{p}) \rrbracket^{w, \operatorname{Dox}(\mathrm{s}), \varepsilon}$ is defined iff

(a) $\operatorname{Dox}(s)$ contains only worlds where $p$ is true (subjective veridicality)

(b) $\quad \varepsilon$ is nonveridical and contains $p$ and $\neg p$ worlds (nonveridicality of emotion)

(c) If defined: $\forall \mathrm{w}^{\prime} \in \mathrm{PE}_{\mathrm{E}}: p$ is true in $w^{\prime}$ (assertion of emotion)

Let us now use this account of exclamation speech acts for our Catalan també $e_{\text {EXPRESSIVE }}$. Note that the emotive assertion of exclamations ('I'm surprised/ amazed at x') is also present in the utterances containing també $e_{\text {EXPRESSIVE }}$. We thus 


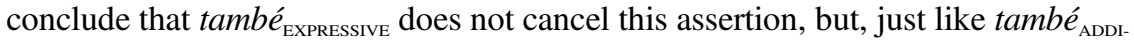
TIVE, conjoins at-issue (emotive assertion) and CI content (negative attitude + argumentative constraints) and is thus of type $\left\langle\mathrm{t}^{\mathrm{a}}, \mathrm{t}^{\mathrm{c}}\right\rangle$, according to the typing of such multidimensional items used by McCready (2010). That is, applying the denotation to a proposition $\varphi$ yields ' $\varphi$ : $\mathrm{t}^{\mathrm{a}} \cdot \operatorname{tamb}_{\text {EXPRESSIVE }}(\varphi): \mathrm{t}^{\mathrm{c}}$ '. In other words, according to our analysis, també $e_{\text {EXPRESSIVE }}$ applies after the exclamation operator EX.

Given these considerations, the CI content of també $e_{\text {EXPRESSIVE }}$ can be represented as follows, where bad refers to a negative attitude on the part of the speaker (S) and highrel to the constraint of high relevance towards the speaker's goal (for detailed decomposition of such a constraint, see Winterstein et al. 2018: 27-28):

$\llbracket$ també $_{\text {EXPRESSIVE }} \rrbracket=\lambda \mathrm{p} \cdot \operatorname{bad}_{\mathrm{S}}(\mathrm{p}) \wedge \operatorname{highrel}(\mathrm{p}):\left\langle\mathrm{t}^{\mathrm{a}}, \mathrm{t}^{\mathrm{c}}\right\rangle$

In other words, també $e_{\text {EXPRESSIVE }}$ encodes that:

(i) the speaker holds a negative attitude towards 'being surprised about $\mathrm{x}$ ' (the emotive assertion $=p$ ) and

(ii) a constraint stating that 'being surprised about $\mathrm{x}$ ' is especially relevant to the argumentative goal 'a negative attitude can be considered justified by both speaker and addressee'.

Note that according to our approach, both també $e_{\text {ADDITIVE }}$ and també $e_{\text {EXPRESSIVE }}$ are hybrid expressions of type $\left\langle\mathrm{t}^{\mathrm{a}}, \mathrm{t}^{\mathrm{c}}\right\rangle$, the difference being that també $e_{\mathrm{ADDITIVE}}$, in addition to its assertive component, conventionally implicates that its assertion and presupposition are co-oriented towards a goal $H$, whereas també $e_{\text {EXPRESSIVE }}$ conventionally implicates an expressive reading (negative attitude) and a related argumentative constraint, and this reading is conjoined with the emotive assertion of surprise expressed by the exclamation també $e_{\text {EXPRESSIVE }}$ occurs in. Crucially, this assertion features at-issue content and can thus be targeted by truth-conditional denials just as declarative statements featuring emotive predicates can (e.g. A: I'm surprised that he is coming. B: No, you are not.). All in all, the composition of també EXPRESSIVE $_{\text {with }}$ the emotive assertion of surprise $(\mathrm{EX}(\mathrm{p}))$ can be represented as follows, which is very much reminiscent of what has been claimed for discourse particles in other languages (Gutzmann 2009); note that the proposition 'being surprised about x' is $q$ in (42) in order to distinguish it from the descriptive content of the exclamation $(p)$.

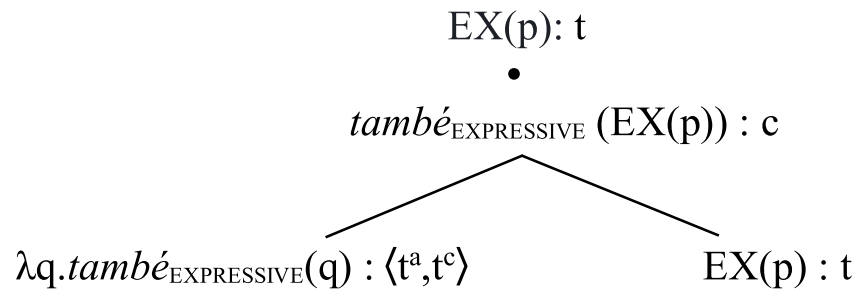

According to this multidimensional analysis, the truth-conditional content is passed up the tree unchanged and the conventionally implicated content sticks within the 
tree and thus cannot participate in any further semantic operations at the root node of the tree (i.e. cannot have any influence on the truth-conditional content of the utterance).

We thus conclude that the two different readings of Catalan també we have illustrated in Section 2 can be captured by the two different denotations given in (39) and (41) above. In particular, in contrast to the additive focus marker també, expressive també conventionally implicates that the speaker has a negative attitude towards the relevant proposition. With these claims and the application of the probabilistic-argumentation framework in mind, let us now turn to a detailed account of our second Catalan particle: precisament.

\subsection{A probabilistic argumentative analysis for Catalan precisament}

Let us now turn to the semantics of precisament in more detail. As we have already pointed out in Section 2.2 above, the import of precisament in examples such as (29), repeated here for convenience as (43), is (i) that the predication does not hold for some other focus alternative, (ii) that there is an identity between the expression in focus and the argument in some other salient proposition, and (iii) that this identity can be considered noteworthy.

(43) I tu, precisament tu! parles de "subvencions"? Quina barra! and you precisely you talk of subsidies which jaw 'And you, of all people, talk about subsidies? What a cheek!'

(https://dbalears.cat/opinio/2016/11/07/295596/quintacolumna-esta-malpler.html)

As already mentioned in Section 2, one could hypothesize that what we see in examples like (43) is basically a likelihood-based presupposition that we also find in the literature on even. In our case, this would translate into something like 'the referent of $t u$ is the least likely person to talk about subsidies'. Note that not only additive even has been analyzed in terms of likelihood, but 'of all X' expressions as well (e.g. Krifka 1995).

However, some qualification is in order here, since some approaches have contested the claim that the scale is really based on likelihood or expectations. Consider the following example by Kay (1990: 84), illustrating that even can be used felicitously when the likelihood-based presupposition is not met:

(44) Everyone is remarking on Mary's improvement. Last week she beat the number ten player and this week, as everyone expected, she even beat the number three player.

In (44), it is explicitly mentioned that it was expected that Mary also beat the number three player, and thus $p$ is marked as fulfilling rather than violating expectations. Nevertheless, even is perfectly fine in such a context. A related observation can be made for precisament in examples like the following: 


\section{CATALAN FOCUS MARKERS AS DISCOURSE PARTICLES}

(45) (a) La Montse treballa a la biblioteca de la universitat i adora/odia la literatura francesa.

('Montse works at the university library and she loves/hates French literature.')
(b) $\mathrm{Li}$ ha tocat her has assigned ocupar-se precisament de la biblioteca. of the library
'She has been assigned precisely to that section of the library.'

The fact that Montse has been assigned to the French literature section of the library is not necessarily more unlikely than all other alternatives (say, the Japanese literature section, which may be smaller and, thus, less likely that one is assigned to work there). Still precisament is acceptable in (45) because it highlights the coincidence in this case between adoring (or hating) French literature and being assigned to work at the French literature section; accordingly, the prejacent of precisament is not surprising by itself.

On the other hand, Kay (1990: 83) has also pointed out examples like (46a), where even is infelicitous although the likelihood-based presupposition is met (see also Greenberg 2016 for recent work on such scenarios). Note that other words, like still, that likewise emphasize the fact that $p$ (here: working hard) can be regarded as violating expectations are felicitous in the same context (46b):
(a) *The boss wasn't there and we even worked hard.
(b) The boss wasn't there and we still worked hard.

Given facts like the ones mentioned above, several characterizations other than likelihood have been suggested to capture all possible scenarios where scalar particles like even can occur felicitously (see Kay 1990 and Herburger 2000). Recently, it has been suggested to replace concepts such as likelihood by a more abstract notion of a contextually supplied gradable property (see Greenberg 2016, 2018). We concur with the general approach articulated in this type of work, and we will thus use the general notion of 'noteworthiness' used by Chernilovskaya (2014) and Nouwen \& Chernilovskaya (2015) in the context of exclamatives because we think that this notion is broad enough to capture all the uses we observe for Catalan precisament. Crucially, we claim that this meaning component is not encoded in the lexical semantics of precisament. Rather, precisament merely points to an identity between two values or arguments in two different propositions, thereby performing an 'emphatic assertion of identity', which has been proposed for similar particles (e.g. German ausgerechnet; see Section 4 below) in the semantics literature by König (1991). However, the semantics of Catalan precisament conveys an argumentative constraint such that 'an identity of $x$ in $p$ and $q$ ' is especially relevant to the argumentative goal 'the identity of $x$ can be considered noteworthy'. Let us look at those separate meaning components in more detail. 
According to our approach, what precisament essentially does in examples like (43) and all the other relevant cases in Section 2.2 above is to point out (i.e. shift the focus of the utterance to) the identity of two values or arguments in two different propositions. The particle can be used either in complex anaphoric situations like (43), or it can also occur in a sentence like (47), where the identity of an argument (here: 'the people'), and not of a whole predicate, is emphatically asserted by using precisament:

(47) La Montse ajuda precisament la gent que l' odia. the Montse helps precisely the people who CL hate 'Montse is helping precisely those people who hate her.'

To approach this interpretation of 'emphatic assertion of identity' and thus the meaning of precisament in examples like (47), let us first adopt and sketch König's (1991) account of 'emphatic assertion of identity', which he formulated for the German particle ausgerechnet (which is very similar to precisament, see Section 4 below). König (1991: 23) proposed to capture the semantics of the focus particle ausgerechnet by means of the collection operator $\gamma$, which has also been used to express identity relations in the context of English cleft constructions (see Atlas \& Levinson 1981: 52-53). In the cleft (48), $\gamma$ forms a term phrase by combining with an open sentence and can be defined as in (49):

(48) 【It was Montse who people hated》

$=[\lambda \mathrm{y} \cdot \mathrm{y}=$ Montse $](\gamma \mathrm{x}[$ hate $(\mathrm{x})($ people $)])$

$=1$ iff $\gamma \mathrm{x}[$ hate $(\mathrm{x})($ people $)]=$ Montse

(49) $\mathrm{B}(\gamma \mathrm{x}[\mathrm{A}(\mathrm{x})])$

$=\exists \mathrm{x}[\mathrm{A}(\mathrm{x})] \& \forall \mathrm{x}[\mathrm{A}(\mathrm{x}) \rightarrow \mathrm{B}(\mathrm{x})]$

When we now turn to our example (47) above and the focus interpretation of precisament, we need a second argument (50) and also would like to say that (47) entails that whenever Montse helps someone, that individual is identical to someone who hates Montse; this is represented in (51): ${ }^{13}$

(50) (a) $[\lambda x \cdot \lambda y \cdot x=y](\gamma x[h e l p(x)($ Montse $)])(\gamma y[$ hate $($ Montse $)(y)])$

(b) $\gamma \mathrm{x}[\mathrm{help}(\mathrm{x})($ Montse $)]=\gamma \mathrm{y}[$ hate $($ Monste $)(\mathrm{y})]$

(51) $\quad \mathrm{A}(\gamma \mathrm{x}[\mathrm{B}(\mathrm{x})])(\gamma \mathrm{y}[\mathrm{C}(\mathrm{y})])$

$=\exists \mathrm{x}[\mathrm{B}(\mathrm{x})] \& \exists \mathrm{y}[\mathrm{C}(\mathrm{y})] \& \forall \mathrm{xy}[\mathrm{C}(\mathrm{y}) \rightarrow \mathrm{B}(\mathrm{x}) \& \mathrm{~A}(\mathrm{x})(\mathrm{y})]$

Given König's (1991) basic insights and his account of the relevant meaning components sketched above, we can now propose our analysis of the focus use of precisament in (52) (precisament $t_{\text {ЕMPнаті }}$ henceforth), for which we adopt the argumentative view by Winterstein et al. (2018) again.

[13] We thank an anonymous $J L$ referee for providing detailed comments about these representations. 


$$
\begin{aligned}
\llbracket \text { precisament }_{\text {ЕMPнAтІC }} \rrbracket= & \lambda \mathrm{Q} \lambda \mathrm{x} .\{\mathrm{Q}(\mathrm{x})=1\} . \exists \mathrm{y} \in \Psi(\mathrm{x})[\mathrm{x} \neq \mathrm{y} \wedge \mathrm{Q}(\mathrm{y})]=0 \\
& \cdot \lambda \mathrm{Q} \lambda \mathrm{x} . \exists \mathrm{R} \in \Psi(\mathrm{Q})[\mathrm{Q} \neq \mathrm{R} \wedge \mathrm{R}(\mathrm{x})=1 \wedge \mathrm{ba}(\mathrm{Q}(\mathrm{x}), \\
& \mathrm{Q}(\mathrm{y}))],
\end{aligned}
$$

in which

- $\mathrm{x}$ is the associate of precisament,

- $\mathrm{Q}$ is the scope of també, the abstraction such that $\mathrm{Q}(\mathrm{x})=$ $\mathrm{p}$, where $\mathrm{p}$ is the proposition precisament combines with,

- $\Psi(\mathrm{x})$ is the set of alternatives of $\mathrm{x}$ and $\Psi(\mathrm{Q})$ the set of alternatives to $\mathrm{Q}$,

- $b a$ expresses that $\mathrm{Q}(\mathrm{x})$ is a better argument than the alternative $\mathrm{Q}(\mathrm{y})$ for the argumentative goal $H .{ }^{14}$

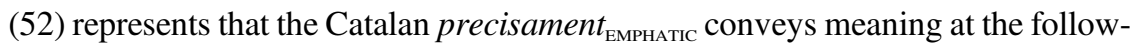
ing separate meaning dimensions:

- It presupposes that the propositional content $p$ is true.

- It asserts that there is (at least) an alternative $y$ to $x$ such that $\mathrm{Q}(\mathrm{y})$ it is not true.

- It conventionally implicates that (i) there is an alternative to $\mathrm{R}$ to $\mathrm{Q}$ such that $\mathrm{R}(\mathrm{x})$ is true and (ii) that $\mathrm{Q}(\mathrm{x})$ is a better argument $(b a)$ for the argumentative goal than the alternative $\mathrm{Q}(\mathrm{y})$.

Note that according to our analysis, an utterance containing precisament ЕМРнAтI $_{\text {is }}$ arguing for the goal 'the identity of $\mathrm{x}$ can be considered noteworthy'. Accordingly, emphasizing that there is an identity between $x$ in two different propositions $\mathrm{Q}(\mathrm{x})$ and $\mathrm{R}(\mathrm{x})$ argues for the goal 'the identity of $\mathrm{x}$ can be considered noteworthy'.

This analysis captures our data given in Section 2.2 above, and it can also account for differences like the following. (53) below is fully acceptable since it is easy to reconstruct the argumentative goal of noteworthiness in the case of a husband being in the same hospital where a cousin works.

$$
\begin{aligned}
& \text { El meu marit està ingressat al' Hopistal de Sant Pau } \\
& \text { the my husband it hospitalized at the Hospital of Sant Pau } \\
& \mathrm{i} \text { la meva cosina treballa precisament allà. } \\
& \text { and the my cousin works precisely there. } \\
& \text { 'My husband is hospitalized at Hospital de Sant Pau and my cousin } \\
& \text { works precisament there.' }
\end{aligned}
$$

In contrast, precisament $t_{\text {ЕмPнAтIC }}$ is pragmatically deviant in examples like (54) because it is not noteworthy at all that a person holds a degree in medicine and that s/he works in a particular hospital.

[14] Note that $b a$ itself is not defined in terms of likelihood for the reasons mentioned above, and thus the relation ba(p,q) is only expressing that $p$ is a better argument than $q$ for the argumentative goal $H$. Note also that $q$ is a variable that is bound in separate 'conventional-implicature dimension', according to Potts (2007b: Section 6). 
(54) \#L' Alba és graduada en Medicina i, precisament, treballa the Alba is graduated in Medicine and precisely works a l' Hospital de Sant Pau. at the Hospital of Sant Pau

'Alba holds a degree in Medicine and precisament works at the Hospital de Sant Pau.'

Moreover, just as we have shown for també $e_{\text {EXPRESSIVE }}$ in Section 3.2 above, we can also demonstrate that the argumentative constraint of precisament EMPнAтIC $_{\text {must be }}$ attributed to the speaker, since it projects under the verb believe; observe the unacceptability of the second sentence in (55):

(55) La Berta creu que el rei va morir precisament a l'habitació on havia nascut, \# però a mi aquesta coincidència no em sembla especialment digna d'atenció. 'Berta believes that the king died precisely in the room where he was born, but I do not find this coincidence particularly noteworthy'.

Given the analysis for precisament $t_{\mathrm{EMPHATI}}$ in (52) above, we can now turn back to our examples from Section 2.2 where the meaning of precisament $t_{\text {ЕMPHATIC }}$ is the same as in the analysis above, but where the particle operates at an illocutionary level. Look at (30) and (31) again, repeated here for convenience as (56) and (57):

(56) A: Saps com està la Maria?

'Do you know how Maria is doing?'

B: Precisament, ahir me la vaig trovar pel carrer. precisely yesterday CL her PST find for.the street '(Funny you should ask this,) I actually bumped into her on the street yesterday.'

(57) A: El que més em preocupa és el llenguatge que el pare fa servir amb la mainada.

'What worries me the most is the language that the father uses with the children.'

B: Precisament la Maria i jo n' havíem estat parlant, precisely the Maria and I PVE had been talking d' aquesta qüestió.

of this issue

'(Funny you should say this,) Maria and I were actually talking about this issue.'

In Section 2.2, we have already pointed out that precisament EMPHATIC $_{\text {in }}$ those examples signals that the speaker has something relevant to say about the issue raised by the addressee, and the fact that the addressee has raised this particular issue can be considered noteworthy. In (56B) for instance, precisament $t_{\text {ЕMPHATIC }}$ does not signal that the speaker's current speech act is conflicting with something (i.e. there 
may not be anything noteworthy in uttering that he saw Maria yesterday), but that the previous question is surprisingly relevant for the speaker.

This use of precisament $t_{\text {EMPHATIC }}$ and its corresponding scope is reminiscent of particles in other languages that operate at the level of the so-called 'conversation

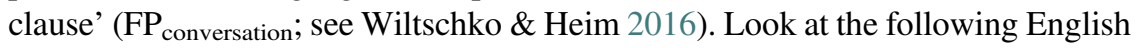
corpus example from Wiltschko (2017: 254):

(58) Katie: Why would he do something like that?

Brooke: Yes, I know. That is the question.

(SOAP corpus; BB-2012-05-23; http://corpus.byu.edu/soap)

In (58), the wh-question can be answered by using polar 'yes' although Speaker B is not responding to Speaker A at the propositional level of CP. Rather, she expresses her agreement that Speaker A's posing of the question is relevant; accordingly, her response operates at the conversational level. Without going into too much detail here, we can say that the basic idea of a syntactic approach distinguishing between these two different scopes is to account for readings like the one illustrated in (58) by postulating a functional projection above the CP level. This projection $\left(\mathrm{FP}_{\text {conversation }}\right)$ encodes parts of utterance that are either referring to previous (as in our case) or future conversational moves (as in the case of 'confirmationals'; see Wiltschko \& Heim 2016). We can illustrate this as follows:

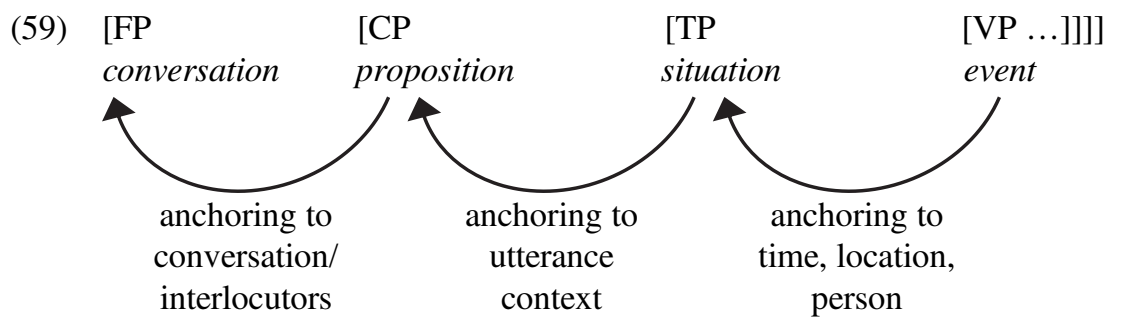

With this approach to encoding conversation-related interpretations of discourse particles, response particles, and other elements in mind, we can now see how the

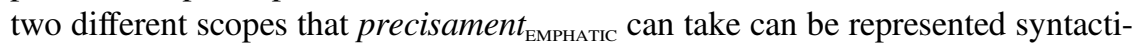
cally. On the one hand, we have discussed 'propositional' precisament EMPHATIC $_{\text {like }}$ in example (60); on the other hand, we can now analyze (61) by postulating that precisament $_{\text {ЕMPHATIC }}$ takes higher scope at the level of the conversational clause:

(60) La Montse treballa a la biblioteca de la universitat i adora/odia la literatura francesa.

('Montse works at the university library and she loves/hates French literature.')

[CP Li ha tocat ocupar-se precisament d'aquesta secció her has assigned deal-CL precisely of.that section

de la biblioteca.]

of the library.

'She has been assigned precisely to that section of the library.' 


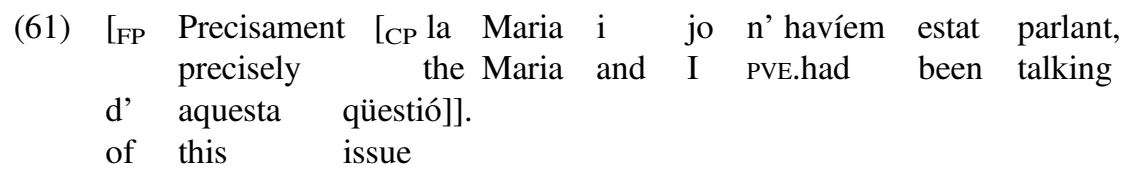

'(Funny you should say this,) Maria and I were actually talking about this issue.'

After having proposed our detailed analyses for the different readings of precisament $_{\text {Емрнатіс }}$ above, we can now ask whether emphasis of the identity of two arguments in different propositions and the argumentative goal of conveying that $p$ can be considered noteworthy may lend itself to further pragmatic effects that are not part of either the denotation or the specific scope-taking of precisament ${ }_{\text {ЕмРнатіс }}$ illustrated above.

In particular, it is obvious that in many of our examples featuring precisament $t_{\mathrm{EM}-}$ рнатіс (e.g. in our key example (43)), the speaker also expresses a negative attitude towards the proposition (further emphasized by continuations like Quina barra! 'What a cheek!' in (43)). However, we would like to claim that unlike in the case of the particle ${ }^{a} a m b e_{\text {EXPRESSIVE }}$, this interpretation is not part of the denotation of precisament $_{\text {ЕМPнAті }}$ and thus totally context-dependent (compare the many other 'non-negative' examples given above). The particle precisament Емрнатіс $_{\text {only con- }}$ veys an evaluatively neutral meaning that we captured above in terms of emphatic assertion of identity and the denotation in (52).

Interestingly, when we now turn to languages other than Catalan, we can observe that it is exactly the other way around: While cognates of també $\dot{e}_{\text {EXPRESSIVE }}$ are emotionally 'neutral', the equivalents of precisament $_{\text {ЕМРнатіC }}$ feature an expression of negative attitude. Let us look at some German data to illustrate this point and then conclude this paper by summarizing and highlighting some cross-linguistic implications.

\section{CRoss-Linguistic IMPLiCATIONS AND THE THIN LINE BETWEen FOCUS MARKERS AND DISCOURSE PARTICLES}

In this paper, we have looked at focus markers that can take on a discourse-particle reading. In particular, we have investigated Catalan discourse particles, which have not been studied from a formal semantics perspective so far. We demonstrated that the Catalan focus adverb precisament 'precisely' and the focus particle també 'also' feature interpretations that we identify as a type of meaning familiar from discourse particles in languages other than Catalan. After having outlined the basic distribution and interpretative effects of these particles in Section 2, we analyzed the semantics and pragmatics of Catalan precisament and també within a probabilistic argumentative framework in Section 3. We concluded that while també $\dot{E}_{\text {EXPRESSIVE }}$ is a particle that conveys a negative attitude on the part of the speaker, the particle precisament $_{\text {ЕмРнаті }}$ lexically conveys an emotionally neutral meaning only, which we captured in Section 3 in terms of 'emphatic assertion of identity'. 


\section{CATALAN FOCUS MARKERS AS DISCOURSE PARTICLES}

With these analyses in place, let us now turn to an interesting cross-linguistic comparison that suggests itself. German is a language where the additive focus particle auch 'too' has a discourse-particle reading as well, just like in the cases we have pointed out for Catalan above. While the standard contribution of auch as an additive focus particle has been analyzed in some depth (e.g. Reis \& Rosengren 1997; Büring \& Hartmann 2001; and many others), its discourse-particle use is acknowledged in the current literature, but it is only listed and mentioned as a side issue and has thus never been accounted for in detail (see e.g. Thurmair 2013). Crucially, when auch occurs in a sentence exclamation (62) or in a $w h$-exclamative (63), it functions just the same as Catalan també $e_{\text {EXPRESSIVE }}$ :

$$
\begin{aligned}
& \text { Du machst auch Sachen! } \\
& \text { you make too things } \\
& \text { 'The things you do!' }
\end{aligned}
$$

(63) Was Du auch für ein Pech hattest!

what you too for a bad.luck had

'What bad luck you had!'

Since this reading of auch in exclamation speech acts has been described as a clear case of a discourse-particle interpretation (Thurmair 2013: 642-643), we can therefore conclude that there clearly is a German counterpart to Catalan també $_{\text {EXPRESSIVE. }}{ }^{15}$

However, in contrast to Catalan també $e_{\text {EXPRESSIvE }}$, which, according to our analysis in Section 3.1, always features an expressive meaning in conveying a negative attitude, the German particle auch does not lexically encode such an attitude. (64) shows again that també $e_{\text {EXPREssIvE }}$ is not felicitous when the speaker is not expressing negative surprise towards the proposition. That is, in (64) també $e_{\text {EXPRESSIVE }}$ can only be interpreted as an additive particle: It is presupposed that other than

[15] There are further particle uses of the particle auch in German that are unrelated to the exclamation meaning we are dealing with here. For instance, auch can function as a marker of rhetoricity in wh-questions (example taken from Trotzke \& Turco 2015: 49):

(i) Wie sollen die armen Mütter auch für diese Dinge aufkommen? how should the poor mothers too for these things pay 'After all, how can the poor mothers pay for these things?'

Another interesting case where the meaning contribution of auch comes close to what we observe in the context of exclamations is the occurrence of auch in 'if'-clauses such as:

(ii) Wenn du dich auch so blöd anstellst! if you yourself too so stupidly act 'You shouldn't be surprised if you act so stupidly!'

Here, too, we observe a negative evaluation on the part of the speaker, which is, however, already present in a version of (ii) without the discourse particle (i.e. Wenn du dich $\varnothing$ so blöd anstellst!). 
having good luck, the addressee did something else (worked really hard to achieve something, for instance).

(64) Quina bona sort has tingut també!

what good luck has had too

[reading: only additive focus marker]

'Also, what good luck you had!'

In contrast to Catalan també $e_{\text {EXPRESSIVE }}$, German auch is perfect in such a context (65):

(65) Was für ein Glück Du auch hast!

what for a luck you too have

[reading: exclamative discourse particle; i.e. no additive reading]

'How lucky you are!'

We thus see that although both també $e_{\text {EXPRESSIVE }}$ and auch can be characterized as particles occurring in exclamation speech acts, only Catalan també $e_{\text {EXPRESSIVE }}$ is confined to contexts of negative surprise. The German particle auch does not add such an evaluative component. Rather, it additionally conveys the meaning of the intended exclamation reading of $w h$-configurations and thus serves as what Grosz (2014b) has called communicative 'cues' in the context of optative clauses in German. In particular, the fact that the German language features a lot of syntactically ambiguous structures such as V2 wh-constructions (which can be either a question or an exclamation) correlates with the fact that this language features many discourse particles that together with other non-syntactic means such as intonation add up to the intended speech-act reading. That is, once auch is added to a structurally ambiguous wh-configuration such as (66a), the construction is disambiguated, and the reading is clearly an exclamation speech act (66b):
(a) Wie groß ist sein Glück?/!
how big is his luck
[reading a: 'How big is his luck?' (= wh-question reading)]
[reading b: 'How big his luck is!' (= wh-exclamative reading)]
(b) Wie groß ist sein Glück auch!
how big is his luck too
'How big his luck is!' (= only wh-exclamative reading)

We would thus like to adopt Grosz's (2014b) proposal and claim that German auch in exclamation speech acts is accounted for by his 'Utilize Cues' framework, which does not posit a direct connection between the respective speech act (in our case: exclamation) and the respective particles in semantics, but rather assumes that there is an interaction established via general principles of communication. Crucially in our context, this also implies that auch in exclamations does not add any 'extra' meaning to the exclamation, in contrast to what we have shown for Catalan: Here, també $e_{\text {EXPRESSIVE }}$ clearly adds a negative interpretation and could thus never occur in examples like German (66b) above, where the speaker can be happy about someone's luck. In other 
words, German auch acts as a disambiguator in wh-exclamatives, given that German wh-exclamatives sometimes feature the same syntactic structure as wh-questions.

Broadening the cross-linguistic perspective further, we thus see that German seems to pattern more with Finnish than with Catalan because in Finnish the additive marker -kin (a clitic corresponding to English too) can also signal pleasant surprise or may just strengthen an exclamation, according to Karttunen (1975) and Karlsson (1999); examples from Forker (2016: 86):
(a) hän
on=kin
3SG
COP.3sG.PRS $=$ ADD pretty
kaunis!
'Ah, she is pretty!'
(b) aurinko paisto-i=kin koko päivä-n
sun shine-PST=ADD whole day-ACC
'And the sun really did shine all day.'

Catalan, on the other hand, seems to pattern more with Mandarin Chinese, where additive markers are used to express a negative evaluation. In this language, for instance, the additive particle $y \breve{e}$ is used to express resignation or (tactful) criticism directed to the addressee, according to Hole (2004: 27). If our observations regarding the Catalan additive focus marker també EXPRESSIVE are on the right track, we may now add Catalan to this class of languages. ${ }^{16}$

Turning back to our comparison of Catalan and German, it is interesting to see that

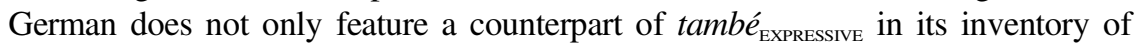

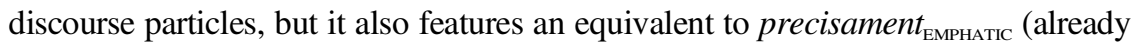
mentioned in Section 2.2): ausgerechnet (lit. 'calculated'). Now, if we turn to this

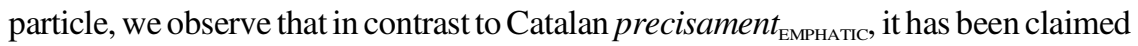
that the meaning of ausgerechnet is always evaluative and characterizes the focus associate as a non-optimal choice; that is, the speaker and/or hearer prefers any other situation than the present one (according to König 2017 and many others). Look at the classic analysis by König (1981), which is using a categorial-grammar framework and assigns particles such as ausgerechnet a category schema where $a$ in (68) is a category variable that stands for all categories that can occur as focus of ausgerechnet:

(68) German ausgerechnet (see detailed analysis in König 1981: 121):

(a) <ausgerechnet, a, $<\lambda, \mathrm{x}<\mathrm{a}, \mathrm{P}>>>$

(b) $(\exists x)(x$ prefers $(y, P)$ to $(a, P))$ for all alternatives $y$ under consideration

It is easy to bring out the evaluative component of the German counterpart of precisament $_{\mathrm{EMPHATIC}}$. For instance, ausgerechnet turns a polar question into a biased

[16] Of course, the idea of a general pattern where focus markers and discourse-particle elements are identical in form goes much further and is further supported by observations for languages that are more closely related to Catalan than German and the other cases cited above. An anonymous $J L$ referee points out that the behavior of French aussi 'too' mirrors what we have pointed out for també, and justement 'exactly' comes very close to our observations in the context of precisament (see Serça 1996). 
question that obligatory conveys a negative evaluation of an affirmative answer. The following example from König (1991: 20) makes this very clear:

(69) Willst du ausgerechnet jetzt verreisen?

want you of.all.moments now go.away

'Of all moments, you want to go away now? (You're acting irresponsibly!')

We thus see that while the evaluative component of Catalan precisament ЕмРнAтіC $_{\text {is }}$ not always present and thus a conversational implicature (see our many data above), it is exactly the other way around in the case of the German counterpart ausgerechnet, following previous work by König (1981, 1991). All in all, while the German cognate of també $e_{\text {EXPRESSIVE }}$ ('auch') lacks an expressive specification, the

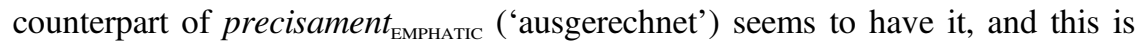
again in contrast to what we see in Catalan.

To conclude, our paper lends support to the central hypothesis that focus markers in many (even typologically less related) languages often have discourse-particle readings, and we hope that future work might detect and identify further discourseparticle elements in languages that are less known for discourse particles, like we have illustrated in this paper for Catalan. A question that has not been addressed by us in this paper is how the more 'regular' uses as focus markers and the discourseparticle uses of the particles are related. We have already highlighted at the outset of the paper that a diachronic investigation is beyond the scope of this paper. However, we have some final thoughts (or better: speculations) about that, which could be a starting point for future investigations: As for the element també, it is hard to see at first sight how també $e_{\text {ADDITIVE }}$ and també EXPRESSIVE are related, given the different analyses and denotations we are proposing in Section 3.2 above. Our hunch is that the 'evidential' component of també $e_{\text {EXPRESSIVE }}$ is in a way additive just as the regular focus use of també $e_{\text {ADDITIVE }}$ is: By using també $e_{\text {EXPRESSIVE }}$, the speaker conveys that the reasons for having a negative attitude must be salient not only for him, but also for the hearer - and we could consider this the 'additive' component of també $e_{\text {EXPRESSIVE }}$. As for precisament, an explanation of how the readings of the manner adverb precisament 'precisely/with precision' and its emphatic focus use (precisament $_{\mathrm{EM}}$ рнатіс) are related seems more obvious: In its emphatic use, the speaker highlights that two elements are the same, and this is noteworthy because one can say 'with precision' that they are the same and thus truly identical. After all, these are just speculations. But the detailed observations and semantic analyses in our paper might help future work to develop a full-fledged theory about the exact historical relations between the different readings and their respective developments.

\section{REFERENCES}

Abels, Klaus. 2010. Factivity in exclamatives is a presupposition. Studia Linguistica 64, 141-157.

Abraham, Werner. 2017. Discourse marker $=$ discourse particle $=$ thetical $=$ modal particle? A futile comparison. In Bayer \& Struckmeier (eds.), 241-280.

Anscombre, Jean-Claude \& Oswald Ducrot. 1977. Deux mais en français. Lingua 43, 23-40. 


\section{CATALAN FOCUS MARKERS AS DISCOURSE PARTICLES}

Anscombre, Jean-Claude \& Oswald Ducrot. 1983. L'argumentation dans la langue. Bruxelles: Pierre Mardaga.

Atlas, Jay David \& Stephen C. Levinson. 1981. It-clefts, informativeness and logical form: Radical pragmatics (revised standard version). In Peter Cole (ed.), Radical pragmatics, 1-61. New York: Academic Press.

Beltrama, Andrea \& Andreas Trotzke. 2019. Conveying emphasis for intensity: Lexical and syntactic strategies. Language and Linguistics Compass 13, e12343.

Büring, Daniel \& Katharina Hartmann. 2001. The syntax and semantics of focus-sensitive particles in German. Natural Language \& Linguistic Theory 19, 229-281.

Castroviejo, Elena. 2006. Wh-exclamatives in Catalan. Ph.D. dissertation, Universitat de Barcelona.

Chernilovskaya, Anna. 2014. Exclamativity in discourse: Exploring the exclamative speech act from a discourse perspective. Ph.D. dissertation, Utrecht University.

Cinque, Guglielmo. 1999. Adverbs and functional heads: A cross-linguistics perspective. Oxford: Oxford University Press.

Coniglio, Marco \& Iulia Zegrean. 2012. Splitting up force: Evidence from discourse particles. In Lobke Aelbrecht, Liliane Haegeman \& Rachel Nye (eds.), Main clause phenomena, 229-255. Amsterdam: John Benjamins.

De Cesare, Anna-Maria. 2015. Defining focusing modifiers in a cross-linguistic perspective: A discussion based on English, German, French and Italian. In Karin Pittner, Daniela Elsner \& Fabian Barteld (eds.), Adverbs: Functional and diachronic aspects, 47-81. Amsterdam: John Benjamins.

Egg, Markus \& Malte Zimmermann. 2012. "Stressed out!" accented discourse particles: The case of doch. In Ana Aguilar Guevara, Anna Chernilovskaya \& Rick Nouwen (eds.), Proceedings of Sinn und Bedeutung 16 (MIT Working Papers in Linguistics), 225-238. Cambridge, MA.

Espinal, Maria T. 2011. Pragmatic particles at the syntax-cognition interface. In Payrató \& Cots (eds.), 49-80.

Forker, Diana. 2016. Toward a typology for additive markers. Lingua 180, 69-100.

Giannakidou, Anastasia \& Alda Mari. 2018. The semantic roots of positive polarity: Epistemic modal verbs and adverbs in English, Greek and Italian. Linguistics and Philosophy 41, 623-664.

Giannakidou, Anastasia \& Alda Mari. 2020. Veridicality in grammar and thought: Modality, propositional attitudes and negation. Chicago, IL: University of Chicago Press.

Greenberg, Yael. 2016. A novel problem for the likelihood-based semantics of even. Semantics \& Pragmatics 9, 1-28.

Greenberg, Yael. 2018. A revised, gradability-based semantics for even. Natural Language Semantics 26, 51-83.

Grimshaw, Jane. 1979. Complement selection and the lexicon. Linguistic Inquiry 10, 279-326.

Grosz, Patrick. 2014a. German doch: An element that triggers a contrast presupposition. In Timothy Grinsell, Adam Baker, Julia Thomas, Rebekah Baglini \& Jon Keane (eds.), Proceedings of the 46th Annual Meeting of the Chicago Linguistic Society (CLS 46), vol. 2, 163-177. Chicago, IL: Chicago Linguistic Society.

Grosz, Patrick. 2014b. Optative markers as communicative cues. Natural Language Semantics 22, 89-115.

Grosz, Patrick. To appear. Discourse particles. In Lisa Matthewson, Cécile Meier, Hotze Rullmann \& Thomas E. Zimmermann (eds.), The companion to semantics (SemCom). Oxford: Wiley.

Gutzmann, Daniel. 2009. Hybrid semantics for modal particles. Sprache und Datenverarbeitung 33, 45-59.

Gutzmann, Daniel. 2015. Use-conditional meaning: Studies in multidimensional semantics. Oxford: Oxford University Press.

Herburger, Elena. 2000. What counts: Focus and quantification. Cambridge, MA: MIT Press.

Hole, Daniel. 2004. Focus and background marking in Mandarin Chinese: System and theory behind cái, jiù, dōu and yĕ. London: Routledge.

Jayez, Jacques \& Lucia Tovena. 2008. Presque and almost: How argumentation derives from comparative meaning. In Olivier Bonami \& Patricia Cabredo Hofherr (eds.), Empirical issues in syntax and semantics 7, 1-23. Paris: CNRS.

Karlsson, Fred. 1999. Finnish: An essential grammar. London: Routledge.

Karttunen, Frances E. 1975. More Finnish clitics: Syntax and pragmatics. Bloomington, IN: Indiana University Linguistics Club.

Karttunen, Lauri \& Stanley Peters. 1979. Conventional implicature. In Choon-Kuy Oh \& David A. Dinneen (eds.), Presupposition (Syntax and Semantics 11), 1-56. New York: Academic Press. 
Kay, Paul. 1990. Even. Linguistics and Philosophy 13, 59-111.

König, Ekkehard. 1981. The meaning of scalar particles in German. In Hans J. Eikmeyer \& Hannes Rieser (eds.), Words, worlds, and contexts, 107-132. Berlin: Mouton de Gruyter.

König, Ekkehard. 1991. Identical values in conflicting roles: The use of German ausgerechnet, eben, genau and gerade as focus particles. In Werner Abraham (ed.), Discourse particles, 11-36. Amsterdam: John Benjamins.

König, Ekkehard. 2017. Syntax and semantics of additive focus markers from a cross-linguistic perspective. In Anna-Maria De Cesare \& Cecilia Andorno (eds.), Focus on additivity: Adverbial modifiers in Romance, Germanic and Slavic languages, 23-44. Amsterdam: John Benjamins.

Kratzer, Angelika. 1999. Beyond ouch and oops: How descriptive and expressive meanings interact. Presented at the Cornell Conference on Context Dependency, Cornell University.

Krifka, Manfred. 1995. The semantics and pragmatics of polarity items. Linguistic Analysis 25, 209-257.

Krifka, Manfred. 1998. Additive particles under stress. Semantics and Linguistic Theory 8, 111-128.

Kripke, Saul A. 2009. Presupposition and anaphora: Remarks on the formulation of the projection problem. Linguistic Inquiry 40, 367-386.

Kuwabara, Kazuki. 2013. Peripheral effects in Japanese questions and the fine structure of CP. Lingua $126,92-119$.

Matthews, Stephen \& Virginia Yip. 2013. Cantonese: A comprehensive grammar. London: Routledge.

Mayol, Laia \& Elena Castroviejo. 2009. Asserted and implicated meanings in Catalan Déu n'hi do. In Arndt Riester \& Torgrim Solstad (eds.), Proceedings of Sinn und Bedeutung 13, 371-384. Stuttgart: University of Stuttgart.

Mayol, Laia \& Robin Clark. 2010. Pronouns in Catalan: Games of partial information and the use of linguistic resources. Journal of Pragmatics 42, 781-799.

McCready, Eric S. 2010. Varieties of conventional implicature. Semantics \& Pragmatics 3, 1-57.

Merin, Arthur. 1999. Information, relevance, and social decision-making. In Lawrence Moss, Jonathan Ginzburg \& Maarten de Rijke (eds.), Logic, language and computation 2, 179-221. Stanford, CA: CSLI Publications.

Mosegaard-Hansen, Maj-Britt. 2018. Particles at the semantics/pragmatics interface: Synchronic and diachronic issues. A study with special reference to the French phrasal adverbs. Leiden: Brill.

Mosegaard Hansen, Maj-Britt \& Erling Strudsholm. 2008. The semantics of particles: Advantages of a contrastive and panchronic approach: A study of the polysemy of French déjà and Italian già. Linguistics 46, 471-505.

Murray, Sarah E. 2017. The semantics of evidentials. Oxford: Oxford University Press.

Nouwen, Rick \& Anna Chernilovskaya. 2015. Two types of wh-exclamatives. Linguistic Variation 15, 201-224.

Paul, Waltraud \& Victor Junnan Pan. 2017. What you see is what you get: Chinese sentence-final particles as head-final complementizers. In Bayer \& Struckmeier (eds.), 49-77.

Portner, Paul. 2009. Modality. Oxford: Oxford University Press.

Potts, Christopher. 2005. The logic of conventional implicatures. Oxford: Oxford University Press.

Potts, Christopher. 2007a. The expressive dimension. Theoretical Linguistics 33, 165-198.

Potts, Christopher. 2007b. Into the conventional-implicature dimension. Philosophy Compass 4, 665-679.

Reis, Marga \& Inger Rosengren. 1997. A modular approach to the grammar of additive particles: The case of German auch. Journal of Semantics 14, 237-309.

Rett, Jessica. 2011. Exclamatives, degrees and speech acts. Linguistics and Philosophy 34, 411-442.

Rigau, Gemma. 2012. Mirative and focusing uses of the Catalan particle pla. In Laura Brugé, Anna Cardinaletti, Giuliana Giusti, Nicola Munaro \& Cecilia Poletto (eds.), Functional heads, 92-102. Oxford: Oxford University Press.

Ruys, Eddy G. 2015. On the anaphoricity of too. Linguistic Inquiry 46, 343-361.

Serça, Isabelle. 1996. À propos de Justement. L'information grammaticale 71, $28-31$.

Simons, Mandy, Judith Tonhauser, David Beaver \& Craige Roberts. 2010. What projects and why. Semantics and Linguistic Theory 20, 309-327.

Thurmair, Maria. 2013. Satztyp und Modalpartikeln. In Jörg Meibauer, Markus Steinbach \& Hans Altmann (eds.), Satztypen des Deutschen, 627-651. Berlin: Mouton de Gruyter.

Tonhauser, Judith, David Beaver, Craige Robert \& Mandy Simons. 2013. Towards a taxonomy of projective content. Language 89, 66-109.

Torrent, Aina. 2011. Modal particles in Catalan. In Payrató \& Cots (eds.), 81-114. 


\section{CATALAN FOCUS MARKERS AS DISCOURSE PARTICLES}

Trotzke, Andreas. 2019. Approaching the pragmatics of exclamations experimentally. In Eszter Ronai, Laura Stigliano \& Yenan Sun (eds.), Proceedings of the 54th Meeting of the Chicago Linguistic Society (CLS 54), 527-540. Chicago, IL: Chicago Linguistic Society.

Trotzke, Andreas \& Anastasia Giannakidou. 2019. Exclamatives as emotive assertions of intensity. Ms., University of Konstanz \& University of Chicago. Available at https://ling.auf.net/lingbuzz/004838 (27 November 2020).

Trotzke, Andreas \& Giuseppina Turco. 2015. The grammatical reflexes of emphasis: Evidence from German wh-questions. Lingua 168, 37-56.

Vallduví, Enric. 1992. The informational component. New York: Garland.

Villalba, Xavier. 2008. Exclamatives: A thematic guide with many questions and few answers. Catalan Journal of Linguistics 7, 9-40.

Wiltschko, Martina. 2017. Response particles beyond answering. In Laura R. Bailey \& Michelle Sheehan (eds.), Order and structure in syntax I, 241-279. Berlin: Language Science Press.

Wiltschko, Martina \& Johannes Heim. 2016. The syntax of confirmationals: A neo-performative analysis. In Gunther Kaltenböck, Evelien Keizer \& Arne Lohmann (eds.), Outside the clause: Form and function of extra-clausal constituents, 305-339. Amsterdam: John Benjamins.

Winterstein, Grégoire. 2011. The meaning of too: Presupposition, argumentation and optionality. In Nick Bezhanishvili, Sebastian Löbner, Kerstin Schwabe \& Luca Spada (eds.), Logic, language, and computation, 322-341. Heidelberg: Springer.

Winterstein, Grégoire. 2012. What but-sentences argue for: An argumentative analysis of but. Lingua $122,1864-1885$.

Winterstein, Grégoire, Regine Lai, Daniel Tsz-hin Lee \& Zoe Pei-sui Luk. 2018. From additivity to mirativity: The Cantonese sentence final particle tim1. Glossa: A Journal of General Linguistics 3, 88. $1-38$.

Zanuttini, Raffaella \& Paul Portner. 2003. Exclamative clauses: At the syntax-semantics interface. Language 79, 39-81.

Zimmermann, Malte. 2011. Discourse particles. In Paul Portner, Claudia Maienborn \& Klaus von Heusinger (eds.), Semantics: An international handbook of natural language meaning, 2011-2038. Berlin: Mouton de Gruyter.

Authors' addresses: (Trotzke)

Fachbereich Linguistik, Universität Konstanz, Universitätsstraße 10,

78457 Konstanz, Germany

andreas.trotzke@uni-konstanz.de

(Mayol)

Departament de Traducció i Ciències del Llenguatge,

Universitat Pompeu Fabra, Roc Boronat, 138,

08018 Barcelona, Spain

laia.mayol@upf.edu 